\title{
The Records of the Human Sciences Research Council ${ }^{+}$
}

\author{
Brown Maaba* (1)
}

Johannesburg Institute for Advanced Study, University of Johannesburg, Johannesburg 2092 South Africa

*Corresponding Author: Imaaba@hotmail.com

\begin{abstract}
The Human Sciences Research Council (HSRC) is South Africa's foremost nonteaching social science research body. In this paper, the author gives an overview of its records, recently uncovered in the institution's building in Pretoria. To academics, policy makers, and all those interested in South Africa's intellectual and institutional history, these records are important in seeking to understanding the HSRC itself and other apartheid institutions. In addition, exploration of its history can, amongst other things, help to shape policy in liberated South Africa towards higher educational and research institutions in the light of their historical legacy of apartheid and segregation. The author cautions that, as researchers embark upon exploring the history of the HSRC, they should avoid romanticizing it but rather confront its nuances and challenges head on.
\end{abstract}

Résumé: Le Human Sciences Research Council (HSRC) est le principal organisme de recherche (et non d'enseignement) en sciences sociales d'Afrique du Sud. Dans cet article, l'auteur donne un aperçu de ses archives, récemment découvertes dans le

History in Africa, Volume 48 (2021), pp. 397-411

Brown Maaba holds a masters degree from the University of Fort Hare and a PhD from the University of Cape Town. His research interest is around South African liberation history, heritage, visual art, and education, and he has published papers in these fields. Maaba is the co-author of the book Education in Exile: SOMAFCO, the ANC School in Tanzania, 1978-1992. He was the Speech Writer for the Minister of Higher Education Dr. Blade Nzimande and subsequently the Speech Writer for the former Executive Mayor of Johannesburg, Parks Tau. Maaba is presently a Research Fellow at the Johannesburg Institute for Advanced Study, University of Johannesburg.

(C) The Author(s), 2022. Published by Cambridge University Press on behalf of the African Studies Association. This is an Open Access article, distributed under the terms of the Creative Commons Attribution licence (https://creativecommons.org/ licenses/by/4.0/), which permits unrestricted re-use, distribution, and reproduction in any medium, provided the original work is properly cited.

doi:10.1017/hia.2021.15

$\dagger$ This article was reviewed internally by the History in Africa editorial team. 
bâtiment de l'institution à Pretoria. Pour les universitaires, les décideurs politiques et tous ceux qui s'intéressent à l'histoire intellectuelle et institutionnelle de l'Afrique du Sud, ces documents sont importants pour tenter de comprendre le HSRC lui-même ainsi que d'autres institutions de l'apartheid. En outre, l'étude de son histoire peut aider à façonner les politiques d'une Afrique du Sud libérée en faveur des établissements d'enseignement supérieur et de recherche à la lumière de l'héritage historique de l'apartheid et de la ségrégation. L'auteur met en garde contre toute idéalisation du HSRC lorsque les chercheur.e.s se lancent dans l'examen de l'histoire de cette institution et les invite à faire preuve de nuance pour comprendre les défis auxquels le HSRC a fait face.

Establishing an archive can be intriguing. This is certainly so with the South African Human Sciences Research Council (HSRC) archives project to which I was appointed as an Archival Researcher by the HSRC in early January 2019. Amongst other things, I was to identify relevant archival material relating to the institution, designated for the organization's digital archive. ${ }^{1}$

On 8 January 2019, I opened a strong-room on the 14 th floor of the HSRC building in Pretoria. Inside were unorganized records of the kind that earlier historians at the HSRC, notably Professors Linda Chisholm and Seán Morrow, had sought in order to write on the history of the institution. Unfortunately, there seemed to be no organizational memory as to the existence of these records and their searches for and enquiries into the institution's records did not lead them to this strong-room. In the end, the two historians soldiered on, using mainly secondary sources to write an article on the institution which appeared in Transformation.

In their article, Chisholm and Morrow highlighted the need for the HSRC to identify and organize its own archive. Unbeknownst to them, the material they so badly needed was locked in the 14th floor strong-room for many years, ironically just behind the Chief Executive Officer's office. ${ }^{2}$

Having worked in the field of history and archives for many years, including as the Content Manager for Digital Images South Africa (DISA), focusing on digitizing South African liberation history records, I understood the kind of material the HSRC needed. I also brought to this task another career element: at the University of Fort Hare in the latter part of the 1990s, I was part of a team charged with organizing the African National Congress (ANC) archives as well as ensuring that sound academic products should emerge from these records. These were challenging times for the institution, as the ANC put pressure on Fort Hare to ensure the success of the archives initiative. I captured these experiences in my $\mathrm{PhD}$ thesis, The History and Politics of Liberation Archives at Fort Hare. Today, the liberation archives at Fort Hare are accessible to the broad scholarly community.

The HSRC is, however, a different beast from Fort Hare, one of the birthplaces of African nationalism. The child of neo-colonialism and

1 The views in this paper are those of the author.

${ }^{2}$ See Linda Chisholm and Seán Morrow, "Government, Universities and the HSRC: A Perspective on the Past and Present," Transformation 63 (2007), 45-65. 
apartheid, it evolved from the National Bureau of Educational and Social Research formed in 1929 and led by Dr. E. G. Malherbe, its first director. Several of the organization's research projects in the past were dubious and sometimes paid attention to issues related only to whites. While assuming white superiority and supremacy, its research interests subsequently extended to black communities. With the coming to power of the National Party, the organization was put to work on the human sciences dimension of the apartheid project. The HSRC benefited greatly and flourished during apartheid, staffed with Afrikaner experts who collaborated unquestioningly with the oppressive state, serving its research and intellectual agenda. ${ }^{3}$ The institution was governed by an Afrikaner-based Council composed almost entirely of Afrikaner academics and administrators and appointed by the Minister of National Education, under which the institution was lodged. At the helm was its President, charged with running the organization and reporting to the Council. The institution's research arms included the following: the Institute for Psychometric Research, which focused on aspects such as the controversial psychometric and intelligence testing; the Institute for Historical Research, which researched areas such as historiography and genealogy; and the Institute for Educational Research, which focused on aspects such as tertiary education and teacher education. The first President of the HSRC was Dr. P. M. Robbertse (1969-1974), followed by Dr. A. L. Kotzee (1974-1979), Dr. J. G. Garbers (1979-1988), Dr. T. van der Walt (1989-1992), and Dr. R. H. Stumpf (19931997), the last HSRC head associated with the apartheid era. ${ }^{4}$

Considering its controversial past, the HSRC cannot escape from some responsibility, even culpability, in relation especially to apartheid education and other areas of social policy and practice under the National Party. Institutions such as the HSRC, the Council for Scientific and Industrial Research (CSIR), the Africa Institute of South Africa (AISA), Rand Afrikaans University, and the University of Pretoria obediently served the racist purposes of apartheid. Parallel to these institutions are liberal institutions such as Wits University and the University of Cape Town, where there was a certain limited space for dissent from the apartheid project, but in which bouts of racism were also evident. ${ }^{5}$

This is the context within which the HSRC, with its questionable past, needs to be looked at. The January 2002 document sent by Mandla Seleoane,

${ }^{3}$ Brahm David Fleisch, "Social Scientists as Policy Makers: E. G. Malherbe and the National Bureau for Educational and Social Research, 1929-1943," Journal of Southern African Studies 21-3 (1995), 349-372; Chisholm and Morrow, "Government, Universities and the HSRC," 45-59.

4 For more on this, see The National Library of South Africa, the HSRC's Annual Reports, 1971-1992.

${ }^{5}$ For more on racism in white institutions, see, for example, Seán Morrow, The Fires Beneath: The Life of Monica Wilson, South African Anthropologist (Cape Town: Pengium Books, 2016), 259-261; Bongani Nyoka, Archie Mafeje: Voices of Liberation (Cape Town: HSRC Press, 2019). 
chairperson of the Transformation Committee at the HSRC, to the Chief Executive Officer (CEO) of the organization at the time, Dr. Mark Orkin, is a case in point. Seleoane urged Orkin to respect workers' rights in his dealings with HSRC staff members and not to think that he could violate such rights with impunity. "One must bear in mind that the rights we have are meant to enable us to live like human beings," he wrote, and continued that "the attack on the rights is therefore an attack on our ability to live like human beings." ${ }^{6}$ This incident took place in 2002, well into democracy in South Africa. It points to the fact that all was not well at the institution.

Some of the problems faced by the institution were literally on its doorstep. For example, the presence of homeless people just outside the HSRC building in Pretoria presented a myriad of intractable problems for the organization. A researcher at the HSRC, Michael Aliber, observed in 2003 that:

\begin{abstract}
Most of the people who spend the night on the HSRC's pavement disappear again every morning by $6 \mathrm{am}$, yet there is growing sense of unsettlement among HSRC staff that something should be done. A fence has been proposed. One concern is that the nightly crowd presents a health hazard to people working at the HSRC building, and keeping the premises clean has become a major daily task for those who tend them.
\end{abstract}

Aliber noted that there were those in the HSRC who held an opposite view on the subject of homeless people:

On the other hand, some HSRC staff express concern that erecting such a fence would be thoughtless and insensitive, not least because poverty is one of the HSRC's principal focus area. Notwithstanding that the HSRC isn't a service agency, how can we simply push poverty away when it appears on our doorstep? Does our social responsibility only extend to collecting and disseminating information? ${ }^{7}$

With the issue of the homeless, extreme poverty was literally at the doors of the HSRC. While the organization was and is dedicated to research, not social services, and while problems of this nature are a reflection of broader socioeconomic conditions in South Africa which are beyond the capacity and remit of the HSRC to resolve, the homelessness issue represents, in extreme form, the uncomfortable realities which it needed and still needs

${ }^{6}$ Paper by Mandla Seleoane: Chairperson of Equity and Transformation at the HSRC, “That We Might Live Like Human Beings: A Reply To Orkin,” 24 January 2002. Thanks to Mandla Seleoane for the paper.

7 Human Sciences Research Council, HSRC Building in Pretoria, 14th floor strong-room (henceforth, H-strong-room), proposal entitled, "Poverty on our Doorstep - What Should the HSRC Do About the People Who Spend the Night at 134 Pretorius Street?," e-mail from Mike de Klerk to Mark Orkin, 28 February 2003. 
to face. Thus, writers on its history certainly need to avoid anything that smacks of romanticism or self-congratulation and directly confront its problems, challenges, and, perhaps, inadequacies. The papers identified in the strong-room are part of the materials for such a project.

This paper is not a detailed history of the HSRC. It is an overview of the institution's archival material, unearthed from the 14th floor strong-room. I cite and quote some of the documents from the consignment that I find interesting in an effort to whet the reader's appetite and to give a sense of the texture of the collection. I will leave it to other scholars to delve into a more thorough history of the HSRC, hopefully providing a balanced and objective analysis of the institution that does not ignore the ambiguities and inconsistencies that marked and still mark it.

\section{The Nature of the Material}

The sizeable archival consignment retrieved mainly from the 14th floor strong-room at the HSRC includes correspondence, minutes, memorandums, reports, and a few speeches. The documents are mainly in English or Afrikaans and are mostly typed.

The use of Afrikaans as a medium of communication at the HSRC prior to the democratic dispensation in South Africa is a reflection of the organization's history and character. Afrikaans was the heartbeat of Afrikaner nationalism, power, politics, and domination, the glue that held die volk, the Afrikaner nation, together.

There are a few documents in the collection that are in both Afrikaans and English. One of them outlines the mission of the HSRC and helps the reader to understand the mission and vision of the organization under apartheid. It explains that:

Die missie van die RGN is om vavorsing te onderneem en te bevorder met
die oog op werbare oplosssings vir menslike vraagstukke. Hierdie oplossings
word in die vorm van navorsingsgebaseerdie inligting, produkte en dientse
aaan 'n wye verskeidenheid belanghebbers in die openbaare en privaatsek-
tor, sowel as aan die algemenepubliek, voorsien.

The mission of the HRSC is to conduct and promote research with a view to finding viable solutions to human issues. These solutions are provided in the form of research-based information, products and services to a wide range of stakeholders in the public and private sectors, as well as to the general public. ${ }^{8}$

Another is a preface by Garbers, the head of the HSRC, during an academic conference, celebrating the 10th anniversary of the organization in 1979. At

${ }^{8}$ H-strong-room, document entitled "Die Missie van die RGN [The Mission of the HSRC]," n.d. 
this conference, 48 papers were presented, some in English and others in Afrikaans. This conference was organized in collaboration with the CSIR. ${ }^{9}$

The end of apartheid and the commencement of the democratic dispensation signalled a drastic reduction in the use of Afrikaans as a medium of communication at the HSRC. When Orkin, a liberal and rather larger-thanlife figure, took over the reins at the HSRC in 2000, this implied, amongst other things, that there was no turning back in ensuring that English must be the main medium of communication at the institution.

Even before Orkin took over at the HSRC, English had already come to be used quite widely at the institution, dating back to the early 1990s. Thus in the HSRC strong-room archival collection there are two sets of documents: those in Afrikaans and mostly produced prior to the democratic dispensation of 1994 and those in English mostly produced in the post-apartheid period. But researchers and all those working on the HSRC digital archive should be mindful that there are a handful of documents in English produced prior to 1990. Researchers navigating the HSRC digital archive should bear in mind that they are dealing with a collection in both English and Afrikaans.

\section{Correspondence}

The strong-room material includes internal and external correspondence on a range of issues. This dates back from the 1970s to beyond 2000, most of it being from the 1980s and the post-apartheid era. It includes correspondence to and from funders, government departments, civil society, universities, international organizations, and sometimes South African-based embassies.

Correspondence prior to 1990 includes, for example, that between the HSRC, the Claude Leon Foundation, and the Percy Fox Foundation. Garbers served as an advisory board member of both these foundations in his capacity as the head of the HSRC. Both foundations focused on giving awards to outstanding individuals in the country, including academics and others of social standing. In Garbers' own words, "the scheme allows recognition and reward for services rendered to society over a wide spectrum."10

Those nominated for awards included celebrated figures such as Philip Tobias, Ellen Kuzwayo, Friday Mavuso, and Wiseman Nkuhlu. For example, Tobias' and Kuzwayo's names were amongst the five names submitted for nomination in 1982 by the Wits University Vice-Chancellor, Professor D. J. du Plessis, in time for the 1983 awards. ${ }^{11}$ Throughout the 1980s, Garbers had an extensive correspondence with these two

${ }^{9}$ H-strong-room, conference proceedings entitled, "RSA: Its People and Their Future," vol. 1.

${ }^{10}$ H-strong-room, letter from J. G. Garbers to an unidentified individual, 23 July 1984.

${ }^{11}$ H-strong-room, letter from C. A. Earle to J. G. Garbers, 19 October 1982. 
foundations, and with universities, regarding the nomination of exceptional South African scholars for awards.

This correspondence is both in English and Afrikaans. Writing to A. H. Leon of The Claude Leon Foundation in 1983, Garbers noted that:

there is indeed an urgent need for scholarships to attract the best brains to those fields where most of the basic problems in our country lie, for instance education, communication and inter-group relations. The fact that the HSRC has received 528 applicants for the 5 available scholarships for 1983 illustrates this. Your bursaries are therefore not only a long-term investment in human potential, but indeed also worthy of the far-sightedness of the Founders of the Foundation. ${ }^{12}$

When Stumpf became the head of the HSRC in the early 1990s, he carried on with the awards program linked to the two foundations. ${ }^{13} \mathrm{He}$ also wrote a generic letter on 21 March 1994 to universities and other organizations, including those from civil society, about The HSRC's Role in a Changing Societal Order. Even though this is a generic letter sent to many institutions in South Africa, it highlights an important aspect of an organization repositioning itself away from the apartheid past which it represented in a changing South Africa. ${ }^{14}$

There is a letter written by Orkin and Dr. Olive Shisana, the latter an Executive Director at the HSRC at the time, to Nelson Mandela, thanking the Nelson Mandela Foundation for the generous offer made to the HSRC's HIV/AIDS program. They wrote:

\section{Dear Mr. Mandela}

On behalf of the Human Sciences Research Council (HSRC), through this letter, we express our deepest appreciation and gratitude for the contribution you have made to the initiation of a social research programme on HIV/AIDS. The generous contribution of R3 836000 that the Nelson Mandela Foundation made to the HSRC to support the conduct of research on the social aspects of HIV/AIDS and to provide technical assistance to the Nelson Mandela Children's Fund and the Foundation will go a long way to contribute to the development of intervention-type of research aimed at prevention, care and mitigating the impact of the HIV/AIDS epidemic in the Southern African region. ${ }^{15}$

12 H-strong-room, letter from J. G. Garbers to A. H. Leon, 11 April 1983.

13 H-strong-room, letter from D. J. du Plessis to R. H. Stumpf, 9 February 1993.

${ }^{14} \mathrm{H}$-strong-room; for more on this generic letter from Stumpf, see, for instance, letter from R. H. Stumpf to Mildred Lesia, 21 March 1994; letter from R. H. Stumpf to A. Boesak, 21 March 1994; letter from R. H. Stumpf to J. Mosala, 21 March 1994.

15 H-strong-room, letter from Mark Orkin and Olive Shisana to Nelson Mandela, n.d. 
For Mandela, this offer was not merely symbolic. The scourge of AIDS affected his immediate family. His only surviving son, Makgatho, also succumbed to the epidemic. ${ }^{16}$

A letter from the South African Human Rights Commission to Orkin on 13 July 2001 invites him to a World Conference against Racism, Racial Discrimination, Xenophobia and Related Intolerance, scheduled to take place in Durban from 31 August to 7 September 2001. The Human Rights Commission informed Orkin that it was "not without significance" that the conference was taking place in South Africa:

It is here that the world community was focused since 1960 to fight apartheid and declare that doctrine a crime against humanity. That has made possible subsequent international actions related to former Yugoslavia and Rwanda. Some of its elements can be found in the Rome Statute of the International Criminal Court.

\section{This letter went on:}

While the world applauds the demise of apartheid, of even more interest, is what is being done in South Africa today to correct the legacy of apartheid. The World Conference Against Racism therefore is an opportunity to showcase South Africa and her struggles to create a land of equality, opportunity and social justice without regard to race or colour. ${ }^{17}$

There is also correspondence between members of the board, its chairperson, and the HSRC management. There is no doubt that commitments of some board members elsewhere took their toll. On 11 December 2001, Dr. Vincent Maphai, a member of the HSRC board, informed its chairperson, Professor James Gerwel, that:

I have increasingly become uncomfortable about my high rate of absence from the HSRC board meetings. This is hardly intended but the result of pressures that one increasingly faces. I just wanted to record my apologies especially that this is something I should have raised with you much earlier. May I suggest that we look at how the New Year will open and reassess the matter next year? I do not feel comfortable simply being a paper member. This must irritate colleagues on the board. ${ }^{18}$

16 “Mandela's Remaining Son Dies of Aids," The Telegraph (6 January 2006), https:/ / www.telegraph.co.uk/news/1480539/Mandelas-remaining-son-dies-of-Aids. html, (accessed 20 February 2019).

17 H-strong-room, letter from South African Human Rights Commission to Mark Orkin, 13 July 2001.

${ }^{18}$ H-strong-room, letter from Vincent Maphai to Jakes Gerwel, 11 December 2001. 
There is also correspondence between the HSRC and the South African Democracy Education Trust (SADET). SADET was charged with re-writing the history of the struggle in South Africa, 1960-1994, with the endorsement of the then state president, Thabo Mbeki. The involvement of the HSRC in the project highlights the organization's efforts to embrace black history, something that would have not happened during apartheid times. The involvement of black researchers from the HSRC in the project - Dr. Greg Houston, Nhlanhla Ndebele, and Moses Ralanala marked the arrival of black writers as a major force in South African historiography. ${ }^{19}$ It would be interesting to examine in detail the role of black researchers at the HSRC and their contribution to scholarship. However, though the likes of Ndebele and Ralanala were involved in important research projects such as SADET, their stay at the HSRC was short. It is thus equally important to examine why many black researchers spent only short periods of time at the HSRC, particularly considering the institution's racist and apartheid past.

A memorandum written on 6 August 2003 by political scientist Dr. Roger Southall summarized the need for transformation at the HSRC:

During its process of transformation, the HSRC has become increasingly conscious about the urgent need for achieving representivity amongst our EDs [Executive Directors]. At the moment, amongst our 10 EDs, we have only 4 who are black. And recent attempts to appoint an African ED within the CEO's office have had to be put on hold. We all know the historical reasons for the shortage of highly qualified, black social scientists who are appointable as EDs given the qualities which are required by the latter: administrative and entrepreneurial abilities combined with a distinguished record in social science research.

Southall did not end there. He further asserted that:

this is all the more reason for us to be pro-active and creative so that when a suitable candidate does hove into view that we should be ready to move, and to move fast. In turn, this means we have to, bluntly, set in position a system whereby white EDs who are mid-contract can be invited to move aside, to a position of equivalent standing, to make way for a potential, probably already identified or head-hunted successor. ${ }^{20}$

Southall's concerns were raised as far back as 2003, but, to date, the HSRC has not had a reasonable number of African Executive Directors in their

19 H-strong-room, letter from Roger Southall to Ben Magubane, 26 March 2002; letter from Roger Southall to Yvonne Muthien, 8 April 2002; letter from Roger Southall to Ben Magubane, 26 March 2002.

${ }^{20}$ H-strong-room, “Achieving Representivity among Executive Directors," by Roger Southall, 6 August 2003. 
governing structures. In 2019, there was only one African Executive Director, Dr. Temba Masilela. This is worrying, considering the burning issue of transformation in South Africa.

\section{Reports}

There are also reports in the collection on a range of issues. Of interest are reports on workshops held by the institution in 1994 in various parts of the country on the "HSRC's role in a rapidly changing societal order." It was clear to the organization that the new era was dawning on the horizon and that apartheid and segregationist policies were retreating. In particular, transformation of the education landscape was inevitable in liberated South Africa. The authorities at the HSRC were fully aware of these developments, which explains the importance of these workshops focusing on the future of the HSRC. They can be seen both as a contribution to the new dispensation and as a justification of the continued role of the organization in the unpredictable era then beginning.

By 5 April 1994, the HSRC had held nine workshops in different parts of the country: three in the PWV area, now Gauteng; two in Bloemfontein; one in Durban; and another in Port Elizabeth. Six of the workshops were aimed primarily at tertiary institutions and Non-Governmental Organizations (NGOs) as well as the private sector. Three were mainly intended for representatives of the non-tertiary educational sector. ${ }^{21}$ Over two hundred people attended these, from academia and civil society. ${ }^{22}$

Debates about the future of the HSRC are captured in the reports emanating from these workshops. Some participants argued that there was no need for the HSRC since universities and NGOs could cover the work it was doing. Some argued in favor of continuity, considering the reconstruction and renewal program associated with liberated South Africa. ${ }^{23}$ Others thought that if the HSRC continued to exist, its research work had to be peer reviewed. In addition, they argued, the institution needed to establish research partnerships with universities, technikons, NGOs, labor, and business. ${ }^{24}$

21 H-strong-room, letter from R. H. Stumpf to S. Mathe, 5 April 1994.

${ }^{22}$ H-strong-room, letter from R. H. Stumpf to M. C. J. Mphahele, 14 March 1994; letter from R. H. Stumpf to M. C. J. Mphahele, 14 March 1994; letter from R. H. Stumpf to Jaycee Montoedi, 22 March 1994; letter from R. H. Stumpf to E. A. Ngara, 22 March 1994.

23 H-strong-room, report on the HSRC Stakeholder Discussion Session of 15 February 1994 - held at Midrand.

${ }^{24}$ H-strong-room, report on the HSRC Stakeholder Discussion Session of 2 March 1994 - held at Port Elizabeth. 
There were many such workshops at the beginning of the new era in South Africa, founded on a sense of optimism and geared towards finding lasting solutions for a broken country after the brutal encounter with apartheid. The impact of these workshops is difficult to assess and was perhaps generally negligible. It is clear that most did not achieve what they set out to do. However, in the case of the HSRC, progress was made: the institution was preserved and a drive, which had already begun in the late 1990s, was made towards transforming it. ${ }^{25}$ In post-apartheid South Africa, the HSRC was housed under the Department of Arts and Culture, Science and Technology (DACST). When the department was split into the Department of Arts and Culture (DAC) and the Department of Science and Technology (DST), the HSRC was housed under the latter. Today, it is under the Department of Higher Education, Science and Innovation. This follows the merger of the DST and the Department of Higher Education and Training (DHET) in 2019.

In the democratic dispensation, the organization has become more diverse, with respected left-leaning South Africa academics such as Orkin, Shisana, Dr. Adam Habib, Dr. Xolela Mangcu, and Professor Crain Soudien, and sometimes also eminent expatriates, taking prominent roles. The institution has been able to leverage its position within and outside government circles, securing research projects and funds, including from the international funding community, which became willing to support governmentlinked organizations such as the HSRC after apartheid. Some of these progressive academics became CEOs of the organization: Orkin from 2000 to 2005; Shisana from 2005 to 2015; and Soudien from 2015 to 2020. The diverse HSRC Council, also staffed with progressive individuals such as Professor Jakes Gerwel and Professor Njabulo Ndebele, has been able to give a positive image to the organization that the funding community and government departments could identify with. ${ }^{26}$

Today, the programs run by the institution include, for instance, the following: the Centre for Science, Technology and Innovation Indicators, which addresses statistical and policy research; Democracy, Governance and Service Delivery, which focuses on matters such as social cohesion, social justice, governance, and service delivery; and Economic Performance and Development, which pays specific attention to socioeconomic issues. These and other programs are run more or less as university faculties and are headed by Executive Directors. ${ }^{27}$

${ }^{25}$ Chisholm and Morrow, "Government, Universities and the HSRC," 55-57

26 For more on the HSRC in the post-apartheid South Africa, see the HSRC Reports, 2000-2020, http://www.hsrc.ac.za/en, (accessed 1 March 2021).

27 For more on these programs, see the HSRC Annual Report, 2019/20, http:// www.hsrc.ac.za/en, (accessed 1 March 2021). 
In this collection, there are also reports on the institution's research programs. These cover issues around the viability of the HSRC and the direction it should take in order to remain relevant. ${ }^{28}$ The implication here is that research programs cannot be static and should respond to the challenges faced by the society.

\section{Speeches}

There are a few speeches in the collection by members of HSRC management and by government officials. For example, there is a speech by Garbers on 8 March 1986 which he presented at the Carlton Hotel, Johannesburg, when he received the Leon/Fox Foundations Community Relations Award. He stated that he had dedicated 32 years of his career to the study of humanity, particularly of the people of South Africa. In spite of this, he was concerned that, "considering present circumstances in our country, it seems as if efforts at improving community relations through research have not been notably successful." 29

In a speech at an event hosted by the National Research Foundation in Pretoria on 20 May 2002, responding to Professor Sue Parnell's keynote address on Good Governance, Orkin highlighted the challenges faced by human scientists: "A first challenge," he said, "is to collaborate productively with our natural science counterparts to realize the potential synergy - not an easy task when the respective parties talk different languages, at least figuratively and sometimes literally." He also emphasized that though research is important, so are outreach programs pertaining to research and its findings. The third challenge, advised Orkin, is that research should not be undertaken for the sake of it, but should be geared towards uplifting the society. ${ }^{30}$

There are a few speeches by Dr. Ben Ngubane, the Minister of Arts and Culture, Science and Technology between the years 1999 and 2004. Notable is his speech during the meeting in Centurion, Pretoria, at which the HSRC 2000/2001 annual report was presented. In this speech, Ngubane highlighted the Science, Engineering and Technology Institution (SETI) review of the institution, which, he said, recommended that a revamp and overhaul of staffing at the HSRC was needed, enabling the institution to reflect "its very real and widely acknowledged

${ }^{28}$ See, for example, H-strong-room, "An HSRC Research Program: Human Resources Development Planning for the New Millennium” by Dr. Andre Kraak, September 2001.

29 H-strong-room, response of J. G. Garbers on receiving The Leon/Fox Foundations Community Relations Award, 8 March 1986, Carlton Hotel, Johannesburg.

30 H-strong-room, speech by Mark Orkin, Pretoria, 20 May 2002. 
competencies." Ngubane asserted that the institution should emphasize scientific excellence but also ensure strong collaboration and coordination with social scientists from the country's numerous research institutions. He welcomed the appointment of such eminent researchers at the HSRC as Professors Bongani Khumalo and Linda Richter, Doctors Shisana, Anil Kanjee, Meshack Khosa, Andre Kraak, and Mr. Mike de Klerk. ${ }^{31}$

\section{Minutes}

Minutes, stretching from the apartheid to the democratic era and covering various areas of activity, form part of the collection. The oldest documentation in the strong-room is minutes of the National Council for Social Research, the immediate predecessor of the HSRC, often referred to as "the Council." These minutes stretch from 1946 to October 1967, some in Afrikaans and some in English.

The first meeting of the Council was held on 14 March 1946, chaired by advocate A. A. Robert. Present were Professors M. C. Botha, H. Reyburn, and R. W. Wilcocks, Doctors E. G. Malherbe, P. A. W. Cook, and W. de V. Malan, and Mr. M. C. Konkeyand and Mr. G. A. C. Kuschke. The Minister of Education, J. H. Hofmeyer, made opening remarks at the meeting.

This new body of experts was to serve as an advisory committee for the Minister of Education and "would take over the functions of the S.A. Council for Educational and Social Research and those of the National Research Council and Board." According to the chairperson, "it was the opinion of the Minister that the Council shouldn't be a large body and that it wouldn't be necessary, in the first instance at least to be on a statutory basis as was the case with the C.S.I.R." The Council's first task was to "make recommendations to the Minister on the methods to be adopted by it." In addition, "the Bureau of Educational and Social Research would act as the Council's secretariat." The director of the Bureau was expected to form part of the Council. ${ }^{32}$

There are also minutes of Directors' and Executive Committee meetings covering HSRC activities, mostly in the 1980s. These minutes are in Afrikaans and shed light on the HSRC's research activities and on the overall nature and dynamics of the organization in this period.

A few sets of minutes from the 1980s are in English. An example is the minutes of the Advisory Committee of the Institute for Historical

31 H-strong-room, speech by the Minister of Arts, Culture, Science and Technology, at the launch of the HSRC 2000/2001 Annual Report in Centurion, Pretoria.

${ }^{32}$ H-strong-room, minutes of the first meeting of the Council for Educational, Sociological and Humanities Research, Cape Town, 14 March 1946. 
Research held on 4 February 1986 in Pretoria. This meeting was chaired by Dr. J. D. Venter and, amongst other things, it thanked Dr. R. T. J. Lombard for his contribution in the establishment of Genealogy as a science. It was also in this meeting that the issue of the South African Historical Association Project, which received financial and secretarial support from the HSRC, was discussed. ${ }^{33}$ There are also minutes on the establishing of the new HSRC building in Pretorius Street. The series runs from 1979 until the inauguration of the new building in February 1988.

\section{Conclusion}

In South Africa today, there is a growing interest in researching and writing institutional history. Examples are works on universities such as the University of Cape Town and Fort Hare, the Solomon Mahlangu Freedom College (SOMAFCO), the ANC school in Tanzania in exile times, AISA, and even that of the HSRC itself, as was demonstrated in the article by Chisholm and Morrow.

This paper has largely addressed such concerns, bringing the attention of the scholarly community to the fact that there is a sizeable collection of papers on the HSRC which throw light on the institution. The records mentioned in this paper are important, and it is essential that they be preserved particularly through digitization, which nowadays has become crucial to the preservation of archival material. Most important is that these primary sources on the HSRC are of great benefit to historians, political scientists, educationists, and other researchers interested in the history of the organization and in the relationship between influence and research in South Africa. Through the use of such records, ground-breaking research on the institution can be undertaken.

To find out more about the HSRC archival records contact:

Human Sciences Research Council

Private Bag X41

Pretoria

South Africa

0002

Phone number: (012) 302-2000

Fax number: (012) 302-2229

33 H-strong-room, meeting of the advisory committee of the Institute for Historical Research, 4 February 1986, Pretoria. 


\section{References}

Chisholm, Linda, and Seán Morrow, "Government, Universities and the HSRC: A Perspective on the Past and Present," Transformation 63 (2007), 45-65.

Fleisch, Brahm David, "Social Scientists as Policy Makers: E. G. Malherbe and the National Bureau for Educational and Social Research, 1929-1943," Journal of Southern African Studies 21-3 (1995), 349-372.

HSRC Annual Report, 2019/20, http:/ /www.hsrc.ac.za/en, (accessed 1 March 2021). "Mandela's Remaining Son Dies of Aids," The Telegraph (6 January 2006), https:// www.telegraph.co.uk/news/1480539/Mandelas-remaining-son-dies-of-Aids. html, (accessed 20 February 2019).

Morrow, Seán, The Fires Beneath: The Life of Monica Wilson, South African Anthropologist (Cape Town: Pengium Books, 2016).

Nyoka, Bongani, Archie Mafeje: Voices of Liberation (Cape Town: HSRC Press, 2019).

Seleoane, Mandla, "That We Might Live Like Human Beings: A Reply To Orkin," 24 January 2002, unpublished paper.

\section{Archival Material}

\section{Human Sciences Research Council Records:}

(i) Correspondence

(ii) Reports

(iii) Speeches

(iv) Minutes 